\title{
A pluralistic conceptual model for affordable housing in Lagos, Nigeria
}

\author{
A. Ogunnaike, G. Squires \& C. A. Booth \\ Construction and Property Research Centre, \\ University of the West of England (UWE), UK
}

\begin{abstract}
Housing is one of the challenges caused by urbanisation in Nigeria. Since independence, it has always been on the agenda of past governments to reduce the housing shortage and improve the quality of housing. In 1991, Nigeria made the paradigm shift from direct provision to enablement strategy as promoted by the United Nations. The housing problem remains intractable especially in the urban centres across the country forcing many urban residents to continue to live in poor housing conditions. It therefore becomes necessary to re-examine the affordable housing agenda in a new perspective. This contribution is an attempt to offer solutions to the perennial housing shortage in Lagos, Nigeria, drawing inspirations from an extensive review of literature and suggesting a new pluralistic approach. The pluralistic approach consolidates on the gains of a private sector driven approach, while recognising the new roles for the public sector.
\end{abstract}

Keywords: urbanisation, poverty, public housing, Sub-Saharan Africa, enablement strategy, public-private partnership.

\section{Introduction}

Lagos was the capital of Nigeria till 1992 and it is the most populated city in Nigeria and south of the Sahara with a current estimated population of over 15 million. Currently, it is second most populated city in Africa after Cairo and the seventh fastest growing city in the world [1]. Lagos, the city of excellence as it is popularly called, remains the economic nerve centre of the country with the largest concentration of industries, financial institutions and major sea ports [2]. Due to high rate of urbanisation, Lagos is facing population explosion without 
commensurate level socio-economic infrastructure such as housing needed to sustain itself. UNFPA (2011) estimated that in 2015, Lagos will have 23.2 million inhabitants with estimated urban population of about 15 million. Abosede [3] confirmed $>70 \%$ of the population of Lagos metropolis live in rooming types with occupancy ratio of 8-10 persons per room lacking basic services and amenities required for a healthy living. Researches confirmed there is housing shortage in Lagos, [4] Kabir and Bustani [5] affirmed the housing problem in Nigeria is not only quantity but also quality. Even though, there is no accurate data on housing shortage in Nigeria, Ademiluyi [6] put housing deficit in the country at 15 million houses. Currently, the deficit is estimated at over 25 million. The production of housing in Nigeria is low, only 2 dwelling units per thousand people, compared to the required rate of about 8-10 dwelling units per thousand people as recommended by the United Nations [6]. Nigeria needs one million housing units yearly to meet demand and replenish decaying housing stock [7].

The housing shortage is a national concern. The first civilian administration started the first National Development Plan I (1962-1968), which was aborted in 1966 as the military took power. It only recorded only $2.1 \%$ success. Other housing interventions include the National Development Plans II, III, IV and National Housing Programmes I and II. The performance of past housing programmes by Nigerian governments on the provision of affordable housing has not been impressive. EFINA [8] gave assessment of housing programmes (1975-1995) as shown in Table 1.

Table 1: $\quad$ Assessment of impact of national housing programmes (1975-95).

\begin{tabular}{|l|c|c|c|c|}
\hline & Period & Planned & Achieved & $\begin{array}{c}\text { \% of } \\
\text { Achievement }\end{array}$ \\
\hline $\begin{array}{l}\text { National } \\
\text { Development Plan } \\
\text { - NDP 1 }\end{array}$ & $1962-1968$ & 24,000 & 500 & 2.1 \\
\hline $\begin{array}{l}\text { National } \\
\text { Development Plan } \\
- \text { NDP 2 }\end{array}$ & $1970-1974$ & 54,000 & - & 0.0 \\
\hline $\begin{array}{l}\text { National } \\
\text { Development Plan } \\
\text { - NDP 3 }\end{array}$ & $1975-1980$ & 202,000 & 28,500 & 14.1 \\
\hline $\begin{array}{l}\text { National } \\
\text { Development Plan } \\
- \text { NDP 3 }\end{array}$ & $1981-1985$ & 200,000 & 47,200 & 23.6 \\
\hline $\begin{array}{l}\text { National } \\
\text { Housing Program- } \\
\text { NHP 1 }\end{array}$ & $1994-1995$ & 121,000 & 1,014 & 0.8 \\
\hline
\end{tabular}

Source: EFInA, (2010) citing Pison Housing Company, 2009. 


\section{Affordable housing in Lagos, Nigeria}

The term affordable housing has broadened over time. Affordable housing emerged in the 1990s as a more modern, less stigmatized way to describe housing for the poor, low-income housing, or subsidized housing. Many experts in housing proffered different definitions of affordable housing from national or local perspectives. Katz et al. [9] said that it should rather be considered as a component of a comprehensive strategy for reduction of cost, relative to market housing cost and rental value irrespective of sizes, material applications, maintenance cost and durability for any scheme. Other scholars defined affordable housing as housing targeted at low, moderate and middle-income families. Okehielem [10] stated that in the UK, affordable housing is defined by the local authorities depending on circumstances of local income levels, house prices or rents for different household types including social rented and intermediate housing, provided to specified eligible households whose needs are not met by the market. Affordable housing is defined as adequate dwelling where less than $30 \%$ of monthly household income is devoted to rent, or where the dwelling's purchase price is less than three times a household's annual income [11]. Affordable housing in the context of this paper is not only about the physical provision of housing for every citizen in Lagos but making affordable housing accessible to the low income earners.

The major problem to affordable housing in Lagos is poor supply of housing units. The public and private sectors are involved in housing delivery with the public supplying just $\sim 10 \%$. On the public side are institutions such as the Lagos State Development and Property Corporation (LSDPC), Lagos State Ministry of Housing, Federal Housing Authority (FHA), Federal Ministry of Housing and Urban Development, Lagos State Building Investment Corporation. The housing supply in Lagos has always been dominated by the private sector (formal and informal) between $85 \%$ to $90 \%$ of the total housing stock [12]. The demand for housing in Lagos is largely due to natural population growth and rapid urbanization. Migrants flood Lagos in search of better living conditions, but effective demand is low due to low income. In the Lagos sub urban areas, the demand is not as severe as residents have easier access to land, cheaper or communal labour and local building materials [13]. On the supply side, Lagos has acute shortage of dwellings. The current level of housing production is only two per thousand [6]. In a research conducted by Residential Auctions Company in 2012, Lagos requires 25,000 units annually in order to ease the acute housing deficit in the state which is estimated at 5 million units. This shortage has consequences on access to affordable housing in Lagos.

\subsection{The existing housing supply model}

The current national housing policy, The New National Housing Policy II enacted in 1991 is a result of several attempts to make housing accessible to the masses, the low income earners. The policy tagged 'Housing for All by year 2000 ' is a deviation from the regime of direct provision of housing units as 
practised between 1962 and 1995 in the National Development Plans. This new housing policy was inspired by the United Nations and other agencies for developing countries including Nigeria, advocated concentration on the private markets to determine the production, distribution and consumption of housing [14-16]. The policy is based exclusion of public sector from direct housing supply and the empowerment of the private sector to fully control the property market.

The goal of the housing policy is to stimulate the private sector especially the informal to be able to access housing loans and build homes. In order to achieve its aim, the National housing policy recommended the establishment of the National Housing Fund (NHF) and created the Federal Mortgage Bank of Nigeria as the apex mortgage institution to manage and administer the housing fund. The NHF received contributions from the public and private working class (2.5\% of income), the banks and the insurance companies [17]. This led to establishment of primary mortgage institutions, (PMAs) through which the funds were disbursed. The enabling strategy encouraged private developers to develop housing products for the market. The private developers did contribute some housing products but were not suited for the low income group. EFINA [8] reported that the private developers lacked the capacity to develop housing for low income groups. The private developers developed some private estates which were not affordable to the low income earners. The developers often want a fast return on their investment because of loans from the banks to finance their building projects, their objective is necessarily to get a quick return on their money; hence, developers prefer to sell land or houses out rightly, usually at high prices [7].

The critics of the current national housing policy of enablement believed that the policy is too reliant on the private market to the exclusion of other modes of housing provision from serious policy consideration [16]. This is not to say that the strategy did not have its merits but the governments in developing countries failed to adapt to specific national requirements [15]. According to Ogu and Ogbuozogbe [17] the enabling strategy has the potential to make a huge contribution towards the alleviation of the country's housing problems. The policy encouraged private developers to invest in housing [7]. The mortgage market remains under-developed and the infrastructural development for new estates is almost non-existent. Public housing was neglected in housing policy as it has been claimed that it was a drain on public funds [18].

\section{A pluralistic conceptual framework model for affordable housing in Lagos, Nigeria}

The new pluralistic concept boosts housing supply by expanding the enablers to include the public and the private sectors. The model proposes the re-inclusion of the public sector to build a solid base upon which the private driven housing will thrive. The public sector housing is said to be inefficient [18] but new procurement procedures will reduce the inefficiency and harness the best potential of the private sector through public private partnership [19], 
cooperative housing [20] and housing associations, while enhancing the performance of the drivers; the financial institutions, planning regulations and the market (Figure 1).

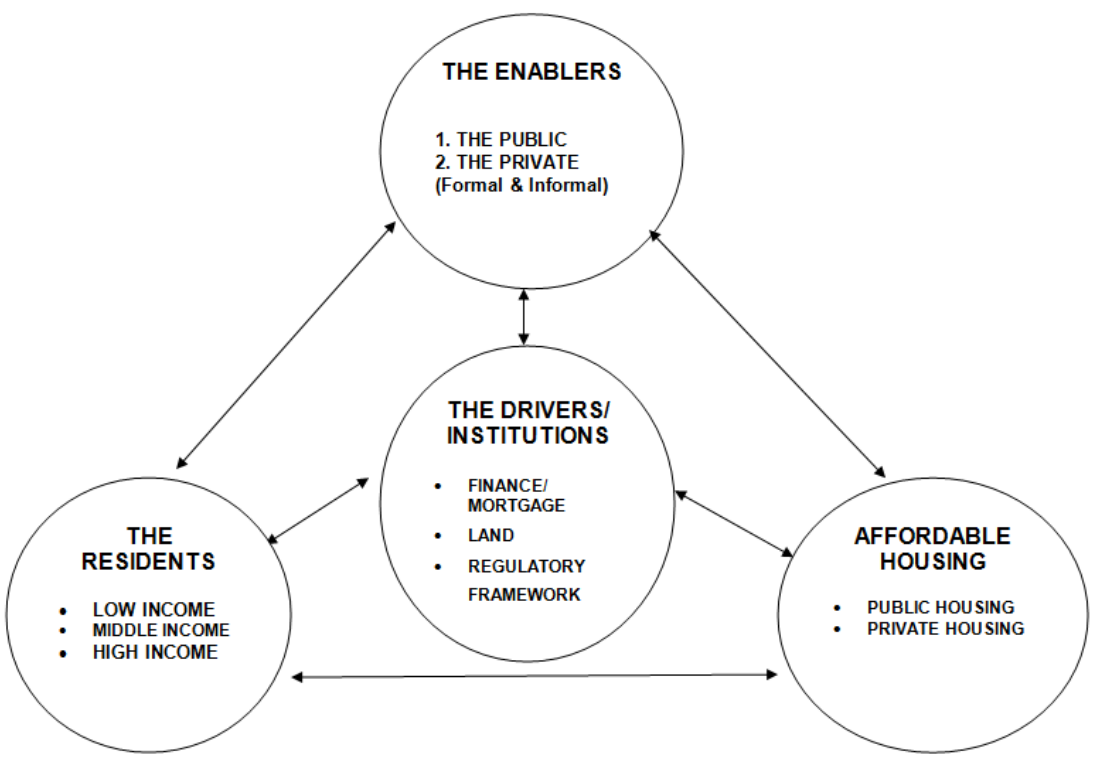

Figure 1: $\quad$ The conceptual framework model.

\subsection{The public sector}

The public consisting of the federal, states and local governments, traditionally initiates public housing projects. However, since the inception of the new national housing programme in 1991 and global paradigm 'enabling strategy' the role of the government in direct provision of housing has reduced. This created a vacuum in the housing delivery as the private sector has not been able to meet met the housing needs of the nation. Ibem [21] confirmed that neither the public nor the private sector can alone address this problem housing situation in Nigeria. The private sector enablement complementing with public housing will not only reduce the magnitude of the deficit but also set standards in the new era of private sector housing. Public housing acts as the base support, upon which private sector housing will build upon. In the pluralistic model, public sector as enabler in housing process will provide support base and enabling environment for optimum performance of the other in the housing sector [21]. The public sector participation will facilitate easier access to land, finance, infrastructure and basic services, the removal of restrictive legislations and strengthen the institutional framework.

The model proposes that to substantially reduce the deficit in housing, public housing participation should be increased. Empirical research has shown that 
public housing content in the total housing stock of most developed nations is high. Other countries such as Australia, Canada and United States are still involved in public housing for the low income groups while encouraging private sector participation. Government agencies can directly or jointly initiate public housing as in public private participation (PPP) or give logistics and for the private sector to operate optimally in housing provision.

\subsection{The private sector}

The private sector consisting of the formal and the informal sub- sectors is the major supplier of housing in Lagos, Nigeria. The formal private sector supplies the housing needs of the middle and upper income groups [8]. Private sector housing is driven by profit motive and not a social service, building private estates and sells to the general public for profit. The houses are usually not affordable to the low income earners. The informal private sub-sector dominates house construction takes care of the low income group in Nigeria with a substantial proportion of the houses constructed outside the official building codes and planning regulations [17]. It has been found that many buildings in the informal market in Lagos were built incrementally due inability to access mortgage finance [22]. Mortgage finance and building materials support will assist incremental housing. Other forms of informal housing include family houses and community or association of age or town groups assist in building houses.

\subsection{Public Private Partnership (PPP)}

Public Private Partnership is a means of veritable tool to address housing shortage combining the efficiency of private sector and the political disposition of the government $[19,21]$. The pluralistic model re-integrates the public role with the private sector to synergize housing production in public private partnership. Though relatively new in Nigeria, it is now becoming popular in Lagos, Abuja and some other urban centres in the country. Kabir and Bustani [5] confirmed that there are several affordable housing schemes that are either fully funded by government or in partnership with the government under the Public Private Partnership (PPPs) scheme. In some cases selected developers were given some kind of concession by government with the aim of providing affordable housing for instance, in Abuja, the Federal Capital Territory. The Public Private Partnership blends with the universal paradigm to increase private participation, reduce direct public involvement in housing and offers a new role for the government to collaborate with the private sector without abdicating totally her social responsibility. The participation of the private sector in affordable housing brings in expertise of the private sector, reducing the risks associated with housing production such as: land problems, access to finance, regulatory framework. Public private partnership with improved access to finance will improve faster delivery of housing projects. The pluralistic model believes that public private partnership will be useful in public housing especially for the very poor who cannot rent at the market rate. 


\section{The driver model for affordable housing in Lagos, Nigeria}

The drivers are tools which will drive the pluralistic model, increasing housing supply (Figure 2). The improved performance of these drivers will contribute easy access to affordable housing. The drivers are: finance, mortgage, land and regulatory framework.

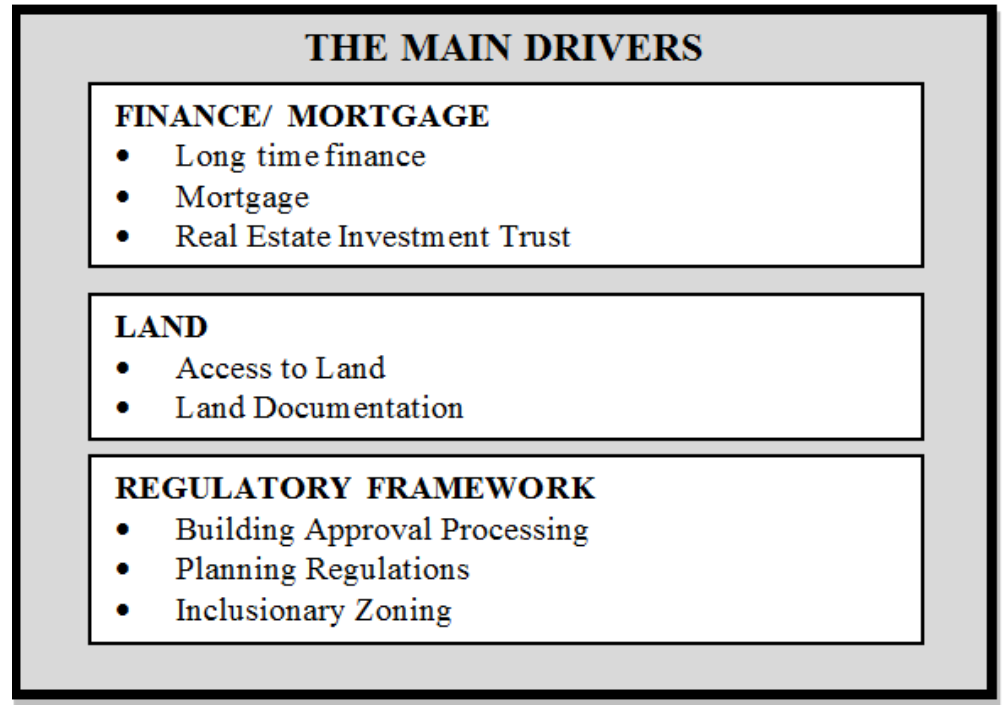

Figure 2: $\quad$ The driver model for affordable housing in Lagos, Nigeria.

\subsection{Finance}

The main driver is sufficient fund. Access to cheaper, long time fund for housing is important in the model. Such funds can be mobilized through specialized banks such as Construction Banks, Pension Funds, and REITs. The level of accessibility to housing finance by the low income earners is still very low despite the intermediary role of private developers and cooperatives [23].

\subsection{Mortgage}

Mortgage finance in Nigeria is still in its infancy and underfunded. Access to mortgage is still difficult as the conditions are very stringent such as certificate of occupancy ( $\mathrm{C}$ of $\mathrm{O}$ ), pay slips where applicable, an approved building plan, registered and stamped by the land registry, beacon numbers on the property and evidence of tax payment [17]. Sanders [24] quoting the US census said that residential mortgage market was the major reason for the high homeownership of $70 \%$ in United States. Similarly, Britain and many other countries in the developed world have vibrant mortgage system. Access to mortgage reduces lengthy incremental home acquisition. 


\subsection{Land}

Land is an important component of housing development process. Access to land is crucial in housing as it is a major barrier to would be investors in housing. However, access to land for housing is problematic in most Nigerian cities [18]. Others called for the amendment of the Land Use Act of 1978 which vests all land in the government is an obstacle to making land available for housing development $[6,25]$. Serviced plots provided by governments are devoid of the usual land titling problems. Delay in titling and land documentation discourages housing development. Speedy land transaction facilitates trading on land as a commodity.

\subsection{Regulatory framework}

Regulatory framework is a tool in housing provision. Government policies should allow the market to work without undue interference. The need for open and free market is not contestable. Rent control was used in Ghana and Nigeria, and was counter-productive [26]. Land documentation in Nigeria takes minimum of 80 days as against one day in some countries like Norway and Singapore [25]. The state government should introduce reforms into building approval processing towards making building approval faster (building approval procedures are cumbersome and take between six weeks to six months). This often discourages developers and lead often to building without building approval. The planning regulations are used to stimulate affordable housing. Inclusion zoning is widely used in the US and Britain to promote the development of low cost housing. Relaxation of some regulations to big developers could act as incentive.

\section{Discussion}

The new pluralistic model relies on enablers (public and the private sectors) and drivers to reduce the accumulated housing shortage and improve the public housing content of the total housing stock. The current enabling strategy, with its propensity to develop the property market for sustainability, has limited success as many low income people did not benefit [8]. The strategy concentrated on enablement of the private sector but did not consider the role of the state in providing social housing to the most poor. The majority of the population earning less than US \$1 per day did not benefit from the housing policy as they are too poor to build or rent decent house [8]. In sub-Sahara Africa countries, including Nigeria, very low income earners are too poor to buy land, properties or rent house at the commercial rate in cities [7, 27].

In view of the absence of direct financial assistance, such as grants for new home, shared home ownership and rental assistance as obtainable in many developed countries, majority of the low income population cannot access mortgages and will continue to live in over-crowded areas. The pluralistic model, redefines the public role as partner in the public private partnership to initiate 
public housing projects, which will cater for low income people. Public housing has been used in many countries to cater for low income people who cannot afford to buy or rent at the market rate [10]. The new pluralistic model encourages public housing using public private partnership to reduce the shortfall in housing provisions and cater for social renting [21].

\section{Conclusion}

The performance of housing policies concern many experts. Some critics believed policies were good but short on implementation, while some believe that the policies were imported without studying its adaptability in Nigerian context and economy. The policy has not been able to reduce the shortage substantially due to several major reasons: poor housing finance, land issues and policy framework. Other reasons include: low per capital income, 57\% of the Nigerian population falls below the poverty line, which is on the average of US $\$ 1$ per day [23] and high cost of building materials.

Most authors accept that access to mortgages is the cause of delay in housing. Cheaper funds, insurance and secondary mortgages will improve housing and assist incremental construction. Land documentation continues to be problematic and discourages would-be investors in housing. The success of the Site and Services Scheme allows many urban poor to access quality housing as it reduces the problem associated with land issue. The amendment of certain laws to enable the framework succeeds is good. The government can accomplish much in the housing sector through concerted efforts in public housing, funding and provide infrastructure and logistics for the private and informal sectors.

Housing is a national asset, an economic activity with inherent multiplier effects. Once the housing sector is buoyant, it will reduce unemployment and contribute positively to other sectors of the economy: commerce, industry, real estate, finance, construction, amongst others. Research into public private partnership, incremental construction, public housing and building materials is important to the success of housing.

The model recommends further research into public private partnership procedures, public housing, incremental construction and local building materials. Public private partnership procurement as a veritable tool for financing and development of housing products, capacity building in the design of low cost social housing. Research into public private partnership will strengthen the role of the public as an enabler. The low income people as an enabler in the pluralistic model builds homes incrementally in Nigeria. Studies into incremental housing will improve the performance of incremental construction. Most of the building materials such as cement, glass and iron reinforcement are imported driving the cost of building up in Nigeria. Building materials constitutes about $60 \%$ of the total building cost [13]. The high cost of building can be reduced by substitution with local materials. The model supports research into building materials to reduce cost housing units. 


\section{References}

[1] City Mayors, The world's fastest growing cities and urban areas from 2006 to 2020, 2011.

[2] National Population Commission, (NPC) Report of the Vision 2020 National Technical Working Group on Housing, 2012.

[3] Abosede, F.B., Housing in Lagos Mega City - Improving Livability, Inclusion and Governance. In: International Conference on Building Nigeria's Capacity to Implement Economic, Social and Cultural Rights held in Abuja in Sept. 2006., in International Conference on Building Nigeria's Capacity to Implement Economic, Social and Cultural Rights, Abuja, 2006.

[4] Coker, A., Awokola, O., Olomolaiye, P. and Booth, C. Challenges of urban housing quality and its associations with neighbourhood environments: Insights and experiences of Ibadan City, Nigeria. Journal of Environmental Health Research, 7, pp. 21-30, 2008.

[5] Kabir, B. and Bustani, S.A. A Review of Housing Delivery Efforts in Nigeria. In: conference on housing assets housing people organized by Dept. of Urban Studies University of Glasgow, UK, 2009.

[6] Ademiluyi, I.A. Public Housing delivery strategies in Nigeria: A historical perspective of policies and programmes. Journal of Sustainable Development in Africa, 12, 2010.

[7] Adejumo, A.A. 30 October 2008. [Online]. [Accessed 16 July 2013].

[8] Enhancing Financial Innovation and Access Report, Overview of the Housing Finance Sector in Nigeria. Finmark Trust, 2010.

[9] Katz, B., Turner, M., Brown, K., Cunningham, M. and Sawyer, N. Rethinking Local Affordable Housing Strategies: Lessons from 70 Years of Policy and Practice. The Brookings Institution Centre on Urban Metropolitan Policy and the Urban Institute, 2003.

[10] Okeleheim, N. A Benchmark for Impact Assessment of Affordable Housing. Wolverhampton: University of Wolverhampton, 2011.

[11] Man, J.Y. Affordable housing in China. [Online]. http://www.lincolninst.edu/pubs/PubDetail.aspx?pubid=1871\&URL=Affor dable-Housing-in-China\&Page $=5$.

[12] Okpala, D.C.I., Housing Production Systems and Technologies in Developing Countries: a Review of the Experiences and Possible Future Trends/Prospects. Habitat International, 16, pp. 9-32, 1992.

[13] Olotuah, A. Recourse to earth for low cost housing in Nigeria. Building and Environment, 37, pp. 123-129, 2002.

[14] Ndubueze, O.J. Urban housing affordability and housing policy dilemmas in Nigeria, 2009.

[15] Yeboah, I.E.A. Housing the urban poor in twenty-first century Sub Saharan Africa: Policy mismatch and a way forward for Ghana. GeoJournal, 62, pp. 147-161, 2005.

[16] Kievani, R, and Werna, E Modes of housing provision in developing countries. Progress in Planning, 55, pp. 65-118, 2001. 
[17] Ogu, V.I. and Ogbuozogbe, J.E. Housing policy in Nigeria: towards enablement of private housing development. Habitat International, 25, pp. 473-492, 2001.

[18] Ikejiofor, U. The God that Failed: A Critique of Public Housing in Nigeria, 1975-199l. Habitat international, 23, pp. 177-188, 1999.

[19] Umar, U. Considering PPP as an Alternative Project Procurement Option. In: Colloquium 2012- Architects Registration Council of Nigeria, Abuja, 2012.

[20] Olotuah, A.O. Cooperative housing for sustainable low income housing development in Nigeria. 2006.

[21] Ibem, E.O. An Assessment of the Role of Government Agencies in PublicPrivate Partnerships in Housing Delivery in Nigeria. Journal of Construction in Developing Countries, 15, pp. 23-48, 2010.

[22] Nubi, O.T. Housing Finance- Nigeria in need of Re-Engineering. Ideal Habitat Cooperative, 2000.

[23] Adedeji, Y.M.D and Olotuah, A.O. An Evaluation of Accessibility of LowIncome Earners to Housing Finance in Nigeria. American- Eurasian Journal of Scientific Research, 7, pp. 23-31, 2012.

[24] Sanders, A. Barriers to home ownership and housing quality: The impact of the international mortgage market. Journal of Housing Economics, 14, pp. 147-152, 2005.

[25] Akeju, A. Challenges to Providing Affordable Housing in Nigeria. In: 2nd Emerging Urban Africa Conference on Housing Finance in Nigeria, October 17-19, Abuja, 2007.

[26] Tipple, A. and Korboe, D. Housing Policy in Ghana: Towards a Supply Oriented Future. Habitat International, 22, pp. 245-257, 1998.

[27] Boamah, N.A. Housing Affordability in Ghana: A focus on Kumasi and Tamale. Ethiopian Journal of Environmental Studies \& Management, 3, pp. 1-11, 2010.

[28] Ibem, E.O. Government Assisted Self Help Housing (GASH) for low income earners in Ogun State: A case study on Workers' Housing Estate, Laderin, Abeokuta, April, 2012, in Architects Colloquium 2012, Abuja.

[29] Johnson, M.P. Decision Models for Affordable Housing and Sustainable Community Development. John Heinz III School of Public Policy and Management Carnegie Mellon University Pittsburgh, PA 15213-3890, 2006.

[30] Olotuah, A.O. and Bobadoye, S.A. Sustainable housing provision for the urban poor: a review of public sector intervention in Nigeria. The Built \& Human Environment Review, 2, 2011.

[31] Peterside, C.S. Policy Foundation for Affordable Housing in Nigeria: Role of the Secondary Mortgage Market, 2003.

[32] Peterside, C.S. Ameliorating Housing Deficit in Nigeria, 2005.

[33] Residential Auctions Company, Outlook, 2012. 